\title{
RANDOM PREVENTIVE MAINTENANCE POLICY BASED ON INSPECTION FOR A MULTICOMPONENT SYSTEM USING SIMULATION
}

\section{OPARTA NA PRZEGLĄDACH POLITYKA LOSOWEJ KONSERWACJI ZAPOBIEGAWCZEJ SYSTEMU WIELOELEMENTOWEGO Z WYKORZYSTANIEM SYMULACJI}

\begin{abstract}
In today's global situation where highly competitive companies demand production efficiently to reduce costs, increase product quality, and customer loyalty, maintenance becomes crucial to achieve this goal by reducing unplanned downtime, reworking of products, and costs. In this sense, the use of models that can represent this type of system, and help managers make decisions more easily, are of vital importance for companies. Thus, a preventive maintenance model for a multicomponent system with different failure mechanisms is proposed in this work. Considering that the objective is to optimize the number and the time of maintenance interventions, that will be done in the system, periodic inspections are carried out in order to minimize the expected costs of maintenance. The optimization was performed with simulation, which proved to be satisfactory, since the decision variables of the model behaved adequately when utilized within the context of an applied case study. In addition, these variables had different performances when analyzed in four different scenarios: the original model of the proposed policy, and three variations attributing costs of penalties.
\end{abstract}

Keywords: random preventive maintenance; inspection; simulation; sugarcane plant.

\begin{abstract}
$W$ dzisiejszej sytuacji globalnej, w której przedsiębiorstwa o wysokim stopniu konkurencyjności wymagaja efektywnego obniżania kosztów produkcji, poprawy jakości produktów oraz zwiększania lojalności klientów, konserwacja ma zasadnicze znaczenie dla osiagnięcia tych celów poprzez redukcję nieplanowanych przestojów, oraz zmniejszenie konieczności usuwania usterek produktów a także obniżanie kosztów. W tym sensie, wykorzystanie modeli reprezentujących tego typu systemy i ułatwiające menedżerom podejmowanie decyzji , ma kluczowe znaczenie dla firm. W tej pracy zaproponowano model konserwacji zapobiegawczej dla wieloelementowego systemu o różnych mechanizmach uszkodzeń. Biorąc pod uwagę, że celem jest optymalizacja liczby i czasu trwania zabiegów konserwacyjnych dokonywanych w systemie, przeprowadzane sq okresowe przeglady mające na celu zminimalizowanie oczekiwanych kosztów utrzymania. Optymalizację przeprowadzono za pomoca symulacji, która okazała się zadowalająca, ponieważ zmienne decyzyjne modelu zachowywaty się odpowiednio przy wykorzystaniu ich $w$ kontekście omawianego studium przypadku. Dodatkowo, zmienne te przybierały różne wartości dla czterech różnych scenariuszy: pierwotnego modelu proponowanej polityki konserwacyjnej i trzech wariantów, w których uwzględniono koszty pracy systemu w stanie awaryjnym.
\end{abstract}

Stowa kluczowe: losowa konserwacja zapobiegawcza; przeglady; symulacja; zakład przetwórstwa trzciny cukrowej.

\section{Introduction}

Many of today's technological systems, such as airplanes, nuclear power plants, military installations, advanced industrial, and medical equipment, involve high levels of complexity in their maintenance and operation and require a high level of availability and reliability [10]. Furthermore, technological companies have been focusing their activities to achieve operational efficiency in a highly competitive global economy.

So, maintenance has been highlighted as a tool for this. It can be said then, that maintenance are technical and administrative actions that can maintain or restore the state of a system, so that the system can perform its required functions to keep it in full operation. These actions classically fall into two categories: preventive maintenance $(\mathrm{PM})$, and corrective maintenance (CM) [1].

PM activities are typically planned to help prevent the deterioration and failure of the system [24], especially when serious consequences due to failure occurs, which may incur very high costs. Besides this, maintenance actions can reduce maintenance costs, and improve the production efficacy of the system, and reliability and availability. However, excessive PM itself can be expensive and time consuming. Therefore, it is important to perform adequate and effective PM practices to balance maintenance activities and cost [27].

An efficient way to perform PM is through inspections. They can have a variable depth level according to the system, and provide information about the system's operating state to perform repairs or replacements [24, 18]. Zhang et al. [26] developed a PM model based on inspection for mechanical components in three states with competing failure modes using an age limit and degradation for the system. Scarf and Cavalcante [20] established a model based on inspection, however for a single component that has three states: good, defective and fail.

Many authors have been using Condition Based Maintenance (CBM) to create models that take into account inspection, among them Lam and Banjevic [16], Chen et al. [5], Zhu et al. [30], Dieulle et al. [9], and Jardine et al. [14]. Other authors have also developed models for maintenance optimization through inspections in different 
segments of, industry such as considering a high-speed milling tool wear by Yan et al. [25], in pipes that undergo corrosion by Sahraoui et al. [21], in reparable multicomponent hospital systems by Golmakani and Moakedi [13], and for the equipment that are inspected by the manufacturers in the warranty period with a cost charged to them, and after this period with the cost charged to the customer [8].

Golmakani and Moakedi [13] were among who developed a maintenance cost optimization model based on periodic inspections for a reparable multicomponent system. Therefore, the main difference between systems with a single component and systems with more than one is that there normally exist some kind of dependence, structure or economic dependence, between them that can be related to the failure mechanism $[4,15]$.

The economic dependence is related to the fact that there can be economic costs when maintenance is performed; the structural dependence is related to the fact that the components form a part, and that maintenance in one implies the maintenance of the other [23]. In addition, the dependency related to the degradation occurs when the failure rates in one component can affect the incidence in another $[7,28]$.

In view of the complexity of the multicomponent systems, the construction of analytical models becomes a very difficult task. Many times, it needs simplifications that affect the ability to represent the main aspects of the real problem. In this sense, what has been seen is a rise in the use of simulation for maintenance optimization. The simulation allows modeling a complex behavior and requires fewer assumptions in relation to analytic modeling.

Although the simulation is well established for representation of the operation of productive systems in general, it is still developing in the maintenance area [3]. Simulation has traditionally been used as a tool to understand and perform experiments with a system. However, combining the simulation model with the optimization model ensures better and faster results $[2,11,12,18]$.

The simulation may incur a number of benefits, among them are experimentation in shorter time, because the model uses a computer; reduced analytical requirements; and more easy demonstration of models. But some disadvantages can also be cited: simulation cannot generate accurate results, when the input date is not accurate as well; and it may not be easy to generate answers to complex problems [6].

In this way, the present paper intends, through the simulation, to obtain performance metrics about one policy, in order to evaluate the effectiveness of a policy that establishes simple procedures for the maintenance manager. Once variations of this policy are shown to be effective, we intend to optimize the policy decision variables for different scenarios, which depict very feasible peculiarities of production systems. The maintenance policy is based on inspections and replacement taking into account opportunities for a system composed of two components whose failure characteristics are different, and which have economic and structural dependency. We used the simulation to find the lowest expected maintenance cost evaluating some decision variables of the model described.

This paper is divided as follows: presentation and description of the proposed maintenance model, with the characteristics of each of the components, an experimental application of the model through a case study in the sugarcane industry, showing the main results for the adopted maintenance policy, and a sensitive analysis about the results to evaluate the variables behavior.

\section{Model Description}

For this model, the follow variables and parameters are used:

Decision variables:

$\mathrm{T}$ : inspection time in A (Cumulative);

$\tau$ : threshold of system age;
$\mathrm{N}$ : Number of inspections in B before $\tau$;

Costs

c1: inspection cost of equipment A.

$c 2$ : inspection cost of equipment $\mathrm{B}$.

$c p$ : replacement cost of A.

$c r$ : system replacement cost $(c p<<c r)$

$c F$ : failure cost of equipment $\mathrm{B}$ - large loss due to the need for aggressive maintenance, besides the lost profit.

$c d t$ : downtime cost.

cB: cost of defect penalty in $\mathrm{B}-$ is counted from the time of the arrived the defect in $\mathrm{B}$ until the moment it is replaced.

\section{Refer to equipment $A$}

$\mathrm{k}$ : number of inspections in $\mathrm{A}(\mathrm{k}=1,2, \ldots)$.

q: number of failures in A.

$\mathrm{y}_{\mathrm{A}}$ : time to arrival the failure in equipment $\mathrm{B}$.

\section{Refer to equipment $B$}

$\mathrm{T}_{\mathrm{B}}$ : time to inspection in equipment $\mathrm{B}$ (Cumulative).

$\mathrm{x}$ : time to arrival of the defect in equipment $\mathrm{B}$.

h: delay time.

$\mathrm{y}_{\mathrm{B}}$ : time to arrival the failure in equipment $\mathrm{B}$, defined as $y_{B}=x+h$.

Refer to system

SL: System Life

C: Maintenance Cost

Consider a system with two units, or a system composed of two basic sets, in parallel, in which the system only stops when component B stops working. Each of the components has a series of particulars characteristics, as shown below.

Equipment A:

1. The failures have an abrupt form. That is, there is not a slow degradation that allows intermediate states before the failure. Component A is working, and suddenly stops.

2. The failure of component $\mathrm{A}$ is not pronounced, because the system does not stop working. For this reason, it is only detected by inspection. This type of failure can be considered as a soft failure [4], because it can reduce the system reliability and increase the risk of damage due to malfunctioning of the system, despite not causing immediate failure of the system.

By the failure characteristics presented previously, they can be classified as hidden failure. According to Taghipour and Banjevic [22], this kind of failure does not stop the system, at the moment that it happens; however, it can cause various types of losses, such as performance (working inefficiently) or economic (low production level or rework). This is because there is a time difference between the occurrence of the failure and its detection $[13,29]$.

3. Component $\mathrm{A}$ is inspected at times $k T$, with $k=1,2, \ldots$, so there is a schedule of inspections to be performed on it in order to identify whether it has already failed or not.

4. The inspection is simple and low cost, and it can be performed visually without using a complex equipment.

5. When a failure occurs, the system has a performance loss, increasing the costs. 
Equipment B:

1. The failure occurs in a slower way, so it is possible to identify intermediate states. That is, before the failure, the equipment presents a defect. In this way, a component type B can undergo three possible states: (1) Operational, (2) Defective, and (3) Fail.

2. Only it is possible to identify that component $B$ is defective in state 2 by an inspection.

3. However, when component B fails, the identification is immediate, because this failure is catastrophic, that is, it brings a damaging consequence to the system. This type of failure is called hard failure [4].

4. Component B is opportunistically inspected. This occurs on inspection of A when it is identified as fail.

5. The inspection in this component is more complex and incurs higher costs than the inspection of A.

In view of the characteristics of the equipment that comprises the system presented previously, and the fact that the inspection of equipment $\mathrm{A}$ is cheaper, as well, due to equipment type B presenting defects, these allows the failures in equipment B to be avoided. So, the following maintenance policy was established:

Equipment $\mathrm{A}$ is inspected at times $k T$, where $k=1,2, \ldots$ If this equipment is in the failed state, equipment $\mathrm{B}$ is inspected. If equipment $\mathrm{A}$ does not present failure, then equipment $\mathrm{B}$ is not inspected. The system is replaced when equipment B failed, or when this is found in a defective state by an inspection, whichever happens first. When an inspection reveal that equipment $\mathrm{A}$ failed, but the equipment is in operational state, only equipment $\mathrm{A}$ is replaced with a new one.

Taking into account that equipment $\mathrm{B}$ failure has repercussions of serious consequences, some maintenance actions are specified for the equipment $\mathrm{B}$, in order to not reach the defective state. The maintenance actions that are performed in equipment $B$ are:

- Inspection when a failure in equipment $\mathrm{A}$ is found;

- Preventive replacement when $N+1$ successive failures have already occurred in equipment $\mathrm{A}$;

- Preventive replacement at the failure time of A, when on failure of A the dispositive B already operated for a longer time than $\tau$.

It is observed that despite the existence of three decisions variables $(N, \tau$, and $T)$, the operation of the model, in practice, is quite simple: there is no pre-scheduled action for both items. It is only subject to corrective maintenance, whereas B will be preventively replaced, when some conditions related to the state of A or the number of failures presented by the item shows an opportunity to replace B.

Here are the ways that the system is renewed:

\section{In failure of $B$}

Figure 1 represents the arrival of the failure moments of equipment $\mathrm{A}$, the time inspection of $\mathrm{A}(T)$, the time inspection of $\mathrm{B}\left(T_{B}\right)$, the defect arrival of $\mathrm{B}$, and the failure time of $\mathrm{B}$ when the system is renewed.

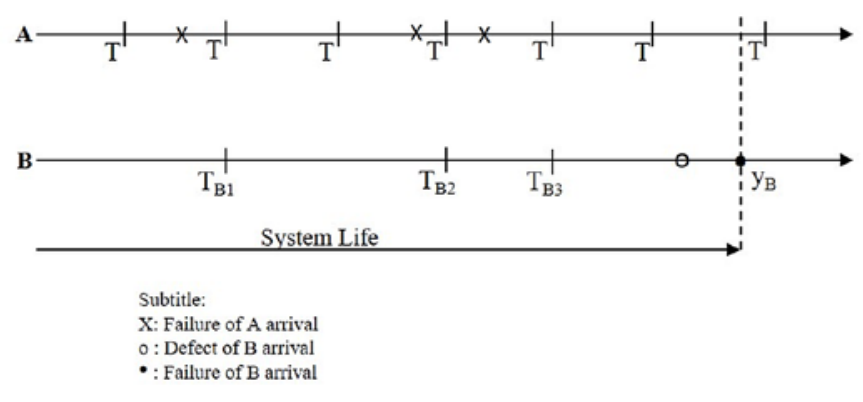

Fig. 1. Representation of the first case of the policy
The System Life $(S L)$ in this case can be presented as follows in Equation 1. It occurs only if the defect and failure of component B happens after the last inspection of $\mathrm{B}\left(T_{B q}\right)$. It is also observed that the condition is linked to the fact that the time of the inspection of $\mathrm{A}$ occurs before or after the limit $\tau$. Therefore, q represents the quantity of inspections in A, pointing out again that the failure of B is the sum of the defect time in B and the delay time.

$S L=y_{B}$ if $x \geq T_{B q} \cap q<N+1 \cap\left\{\begin{array}{c}y_{A} \geq T_{k-1} \leq y_{B} \leq T_{k} \text { if } T_{k}>\mathrm{t} \\ T_{k-1} \leq y_{B} \leq T_{k} \text { if } T_{k} \leq \mathrm{t}\end{array} \quad, k=1,2, \ldots\right.$

We can also study the maintenance costs associated in this case. It is the sum of the inspection costs of A, the replacement cost of A, the inspection costs of component $\mathrm{B}$, the failure cost of component $\mathrm{B}$, and the system replacement cost.

$$
C=\sum_{1}^{k} c 1+q(c p+c 2)+c F
$$

\section{When $q$ is equal to $N+1$}

Taking into account that for equipment $\mathrm{B}$ to be inspected a failure in equipment $\mathrm{A}$ must have be occurred to generate an opportunity to inspect $\mathrm{B}$, and the number of times that the equipment $\mathrm{B}$ was inspected is called $N$, an excessive number of failure may occur in the system without find a defect in B. In this way, to avoid performance losses, in the next failure of A, when $q$ is equal to $N+1$, the system will be renewed without perform inspection in $\mathrm{B}$. This case is showed in Figure 2, where $N$ equals 3 .

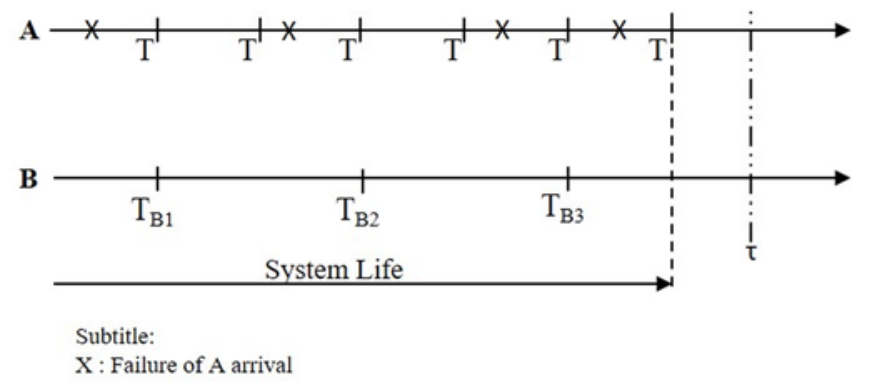

Fig. 2. Representation the second case of the policy

The SL in this case can be presented in this way:

$$
S L=T_{k} \text { if } T_{k} \leq \mathrm{t} \cap x>T_{k} \cap q=N+1, k=1,2, \ldots
$$

The system life will be equal to the last time of inspection of $\mathrm{A}$ $\left(T_{k}\right)$. It occurs if the inspections of B did not find a defect in the dispositive, and also if the time of the $N+1$ inspection of A is less than the limit $\tau$. We can analyze the maintenance costs for this case, in this way:

$$
C=\sum_{1}^{k} c 1+N(c p+c 2)+c r
$$

As highlighted in Equation 4, there is no failure cost added, since it is considered that PM of the system is performed. Consequently, the 
inspection costs of $\mathrm{A}$ and replacement costs of $\mathrm{A}$, together with the inspection costs of B and the system replacement cost, are all added. Note that the number of times that the inspection costs of $\mathrm{B}$ and the replacement costs of A are equal to $N$, because in the $N+1$ failure of A, the policy affirms that the system is replaced, not requiring an inspection of $\mathrm{B}$.

\section{In the first failure of $A$ after $\tau$}

A life threshold $\tau$ of the system is specified due to the fact that there occurs a major performance loss after this time. Besides, it is observed that the probability is great that a defect in B occurs after this limit, and, therefore, a preventive replacement is performed in the first opportunity that A provides. This replacement is performed at the time that A is inspected, because its failures are only detected in these conditions. This case of the policy is presented in Figure 3.

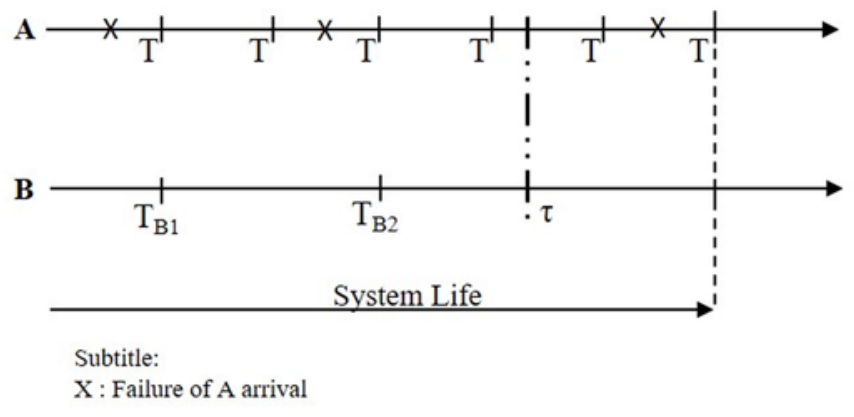

Fig. 3. Representation of the third case of the policy

The SL (equation 5) will be equal to the time of the k-th inspection of A, since it is greater than the time threshold $\tau$, and for this to occur, the arrival time of the defect and the failure of A should be higher than the time of the last inspection. We could analyze the maintenance costs for this case, using the equation 6 :

$$
\begin{gathered}
S L=T_{k} \text { if } q<N+1 \cap x>T_{k}>\mathrm{t}<y_{A}, k=1,2, \ldots \\
C=\sum_{1}^{k} c 1+(q-1)(c p+c 2)+c r
\end{gathered}
$$

In equation 6 , we do not consider the failure cost of $\mathrm{B}$, because we are proposing PM when B reaches a certain age. Accordingly, the cost is composed of the sum of the inspection costs of A, $q-1$ times the inspection costs of $\mathrm{B}$, and the replacement cost of A (because in the last inspection of $\mathrm{A}$, the system is replaced, therefore not needing to inspect $\mathrm{B}$ due to $\mathrm{A}$ is only changed). Besides that, the replacement cost of the system is added.

\section{When to identify a defect in $B$}

This case is characterized when a defect is found on component B through inspection, which is caused by a gradual mechanism of failure that characterizes it. Figure 4 represents this case in which we can identify the defect arrival and the system replacement being performed at $T_{B 3}$.

The SL for this case can be represented in equation 7 below:

$$
S L=T_{k} \text { if } q<N+1 \cap y_{A}\langle\mathrm{t}\rangle T_{k} \cap T_{B(q-1)}<x \leq T_{k}<y_{B}, k=1,2,
$$

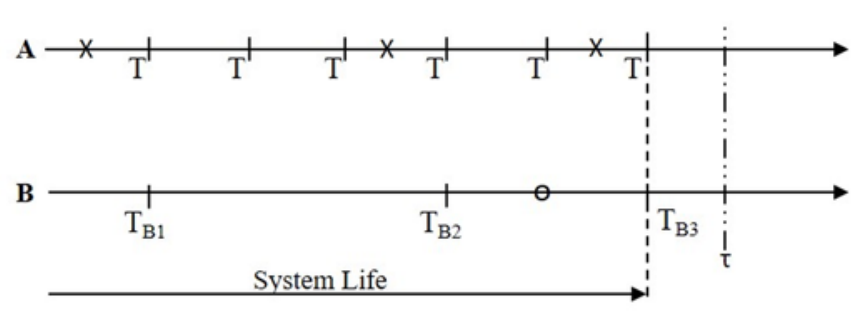

Subtitle:
$\mathrm{X}$ : Failure of A arrival
$\mathrm{O}$ : Defect of $\mathrm{B}$ arrival

Fig. 4. Representation of the fourth case of the policy

Thus, the SL will be equal to the time of the last inspection of A, which will give an opportunity to carry out an inspection of B, and in that inspection, a defect in device B is found. In addition, it is necessary that the failure of $\mathrm{B}$ does not occur. The maintenance costs associated in this case can be expressed by the following equation:

$$
C=\sum_{1}^{k} c 1+(q-1) c p+q c 2+c_{r}
$$

It is possible to verify that the cost of an inspection in $\mathrm{A}$ is the sum $\mathrm{k}$ times the replacement cost of A, added $q-1$ times, and the inspection cost of $\mathrm{B}$ is the sum of $q$ times. This is due to the fact that during the last inspection of $\mathrm{B}$, a defect is found, and therefore the whole system is replaced, not needing to replace only A. In addition, the system replacement cost is added given that there is no failure cost, because we are working with PM in this case.

According Scarf et al. [21], the search for the optimum value of the policy considering the cost minimization, can be calculated by dividing the expected value for the policy cost by the expected value of the cycle size. Thus, the present paper finds the expected value for the cost $E(C)$ and the expected value to the size of the cycle $E(S L)$ by a simulation process (in a free programming software), through the flowchart shown in Figure 5. In addition, we have used a process to optimize the three decision variables of the model: $N$ (number of failures in A), $T$ (time interval of inspections in A), and $\tau$ (threshold of system age), to minimize the total cost of maintenance.

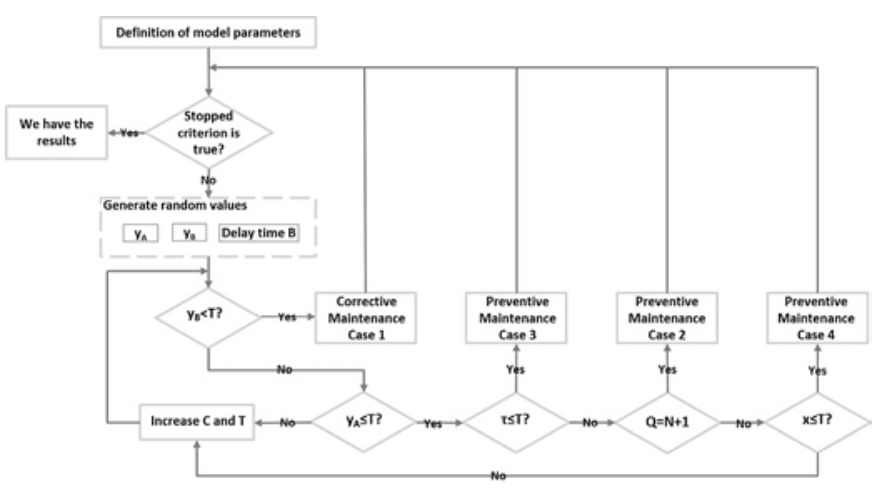

Fig. 5. Flowchart of the simulation process

\section{Case Study}

For this paper we consider a sugarcane plant, whose production of sugar is 40 tons by an hour. For the extraction of the broth of sugarcane, it is first necessary to perform a washing process, then it is minced and defibrated; generally, this set of operations is considered as the process of preparation of the raw material. A machine, namely a sugarcane shredder, is used to open a sugarcane cell, so that the extraction of the broth in the next step of the production process is carried out with greater efficiency. 
The sugarcane shredder is formed by a rotor, to which a set of rotating hammers is attached, so as to force the passage of the sugarcane through a small aperture along a shredder plate. For this study, the set of hammers is called equipment $\mathrm{A}$, whereas the rotor is called equipment B.

The system treated here involves the manufacturing process that uses a perishable raw material, the sugarcane, and as the time interval between the harvest and the beginning of processing increases, the quality of the processed product decreases. After 10 hours, the deterioration begins to have a much steeper curve. Thus, a system shut down by a failure in the set of the system that we are studying can cause a loss of production, both due to the loss of raw materials and the loss of production of the finished product. We can verify the need for periodic inspections of these systems.

A failure in component A may be caused by foreign materials entering with the sugarcane, which was not properly removed during the washing at the beginning of the process, in addition to the natural wear by the effort made by the hammers to defibrate the cane. This failure can generate excessive vibrations and imbalance due to the hammers, causing problems in other equipment such as oil pumps or the rupture of welds in pipes that may lead to loss of steam and oil, and can also cause the accumulation of mass on the sides of the equipment. So, these failures can be characterized by hidden failures, because it can only detected by an inspection on hammers.

Due to the structural dependency between the two components, a failure of the hammer opens an opportunity for the rotor to be inspected to check the existence of a defect. Whereas the failure of the rotor causes the total shutdown of the system, it is the equipment that causes the assembly to rotate for the passage of the sugarcane that will be defibrated. So, due to the characteristics cited above, like the significant failure mechanism, the maintenance cost significant and the dependency, this set is analyzed separately of the whole system.

So, some assumptions of the system are presented:

- The failure of equipment A occurs by an exponential distribution, with parameter $\lambda_{1}$, in which the unit of measurement of failure arrival is months;

- The defect of equipment $\mathrm{B}$ is a random variable $X$ that occur by a Weibull distribution, with parameters $\eta$ (scale) and $\beta$ (shape), evaluated in months;

- The delay time of equipment $\mathrm{B}$ is a random variable $H$ that occurs by an exponential distribution, with parameter $\lambda_{2}$ evaluated monthly;

- The failure of equipment B occurs

by $y_{B}=x+h$;

- The inspections, for both equipment are perfect;

- The inspections times are not significant;

- A failure in equipment B is immediately identified and corrected by a replacement of new equipment, renewing the system;

- On the replacement of equipment $\mathrm{B}$, the system is restored to a new condition.

For the more proper analysis of the maintenance policy shows here, some scenarios were created that are considered possible events in the system presented above. These scenarios can be characterized in this way:

Scenario 1: The failure of equipment A does not cause a loss of performance in the system. This is the general model of the policy, incurring costs according to what showed in the description previously presented.

Scenario 2: The failure in equipment A causes a loss of performance in the system. For this scenario, we consider that equipment A is working in a failure state, that is, there may be some hammer in the set that is not performing the job correctly, causing an accumulation of sugarcane in the corners, as well as not defibrating it correctly. This can result in a loss of quality and quantity of the final product, resulting in more maintenance-related costs.

Scenario 3: The failure in equipment $A$ does not cause a loss of performance (or can be considered null given the low expressiveness), but the defect in equipment $\mathrm{B}$ causes a loss of performance. Because of this, the equipment will work much more in this state, with major costs being the penalty for this situation, for example, rotation set with minor velocity.

Scenario 4: The failure in equipment $A$ causes a loss of performance and a defect in $\mathrm{B}$, too.

The data corresponding to the parameters of the model were collected, and are summarized in Table 1. The units of measurement for the parameters related to time were months and for the monetary costs units per month (\$/month).

The optimal results for the maintenance policy for the four scenarios is in Table 2.

Table 1: Values of the model parameters

\begin{tabular}{ccc}
\hline \hline Parameter & Value & Unit \\
\hline c1 & $0.1 \mathrm{cp}$ & $\$ /$ month \\
$\mathrm{c} 2$ & $0.5 \mathrm{cp}$ & $\$ /$ month \\
$\mathrm{cp}$ & 1 & $\$ /$ month \\
$\mathrm{cr}$ & $10 \mathrm{cp}$ & $\$ /$ month \\
$\mathrm{cF}$ & $25 \mathrm{cp}$ & $\$ /$ month \\
$\mathrm{cdt}$ & 1 & \$/failure time \\
$\mathrm{cB}$ & 10 & \$/defect time \\
$\lambda_{1}$ & 1 & Failure/month \\
$\lambda_{2}$ & 0.66 & Failure/month \\
$\eta$ & 5 & \\
$\beta$ & 2 & \\
\hline \hline
\end{tabular}

For Scenario 1, the optimum policy will be dealing with a cost $\$ 4.759 /$ month, doing periodic inspections in equipment $\mathrm{A}$ in a time

\begin{tabular}{|c|c|c|c|c|c|c|c|c|}
\hline & \multicolumn{2}{|c|}{ Scenario 1} & \multicolumn{2}{|c|}{ Scenario 2} & \multicolumn{2}{|c|}{ Scenario 3} & \multicolumn{2}{|c|}{ Scenario 4} \\
\hline & $\begin{array}{l}\text { Cost } \\
\left(C^{*}\right)\end{array}$ & Parameters & $\begin{array}{l}\text { Cost } \\
\left(C^{*}\right)\end{array}$ & Parameters & $\begin{array}{l}\text { Cost } \\
\left(C^{*}\right)\end{array}$ & Parameters & $\begin{array}{l}\text { Cost } \\
\left(C^{*}\right)\end{array}$ & Parameters \\
\hline Values & 4.759 & $\begin{array}{c}\mathrm{T}=0.9 \\
\mathrm{~N}=4 \\
\tau=4.5\end{array}$ & 4.931 & $\begin{array}{c}T=0.4 \\
N=9 \\
\tau=4.9\end{array}$ & 5.856 & $\begin{array}{c}T=0.8 \\
N=3 \\
\tau=3.2\end{array}$ & 6.017 & $\begin{array}{c}\mathrm{T}=0.4 \\
\mathrm{~N}=7 \\
\tau=3.2\end{array}$ \\
\hline
\end{tabular}

interval of 0.9 months, where $N$ would be equal to 4 and $\tau$ equal to 4.5 months. Therefore, for Scenario 2, in that the failure of A causes losses during the process, it is considered that the best policy would have a maintenance cost of $\$ 4.931 /$ month, with inspection intervals of 0.4 months, where $N$ would be equal to 9 and $\tau$ equal to 4.9 months. For Scenario 3, the optimum would be to have a maintenance cost of \$5.856/month, and inspections should be done at intervals of 0.8 months, where $N$ is equal to 3 and the limit of $\tau$ equal to 3.2 months. In addition, for Scenario 4 , the best value of cost is $\$ 6.017 /$ month, an inspection interval of A equal to 0.4 months, $N$ equal to 7, and a threshold $\tau$ equal to 3.2 months.

With this, it is possible to identify when the failure of the hammer assembly results in an additional cost, such as a penalty for working 
in a failure state, the expected optimum maintenance cost increases, and by contrast, the interval between inspections is shortened. This is because the cost of working with failed equipment is greater than the cost of doing the inspection, which is natural in these types of cases.

In addition, when analyzing an inclusion of cost penalties for the set of rotors to work in a defective state, there is an increase in the expected maintenance cost compared with the original model and the second scenario. This is because sometimes the system will operate with this set in the defective state, for the reason that this defect is only identified in an inspection. Therefore, the time between inspections that was 1.9 months in Scenario 1 decreases to 0.8 in Scenario 3, that is, equipment A (Hammers) is further inspected to provide more opportunities of inspections for equipment B (Rotor) to decrease this added penalty cost. By decreasing the inspection time interval, the amount of times the rotors are inspected may be higher.

If both sets of equipment are working poorly, in a failure state (for A) and in a defective state (for B), this generates additional costs, and the optimal cost expected for the policy increases considerably. The time between inspections decreases in only half a month, because of the fact that the inspection cost is well below the penalty cost.

\section{Sensitive analysis}

To analyze the variation of the optimal values of the policy, one of the fixed parameters was maintained and the other two were varied. The results of these variations are presented below.

Figure 7 presents a variation for the optimal values of the policy for Scenario 1. It is necessary to understand that the interval time between inspections is dependent on the time of $\tau$ and $N$, once there is sufficient time before $\tau$ so that $N+1$ inspections can be carried out, as previously shown in policy description. In this way, when we change the $N$ value for 3 , the maximum time between inspections will be equal 1.1 months, and for $N$ equal to 4 , the time should be lower, until 0.7 months. It can be verified in Figure 6 that there is an apparent variation in the optimum expected cost of maintenance, with the variation of only one $N$ for more and one for less. This is not so evident given the variation of the limit of $\tau$, where the curves overlap.

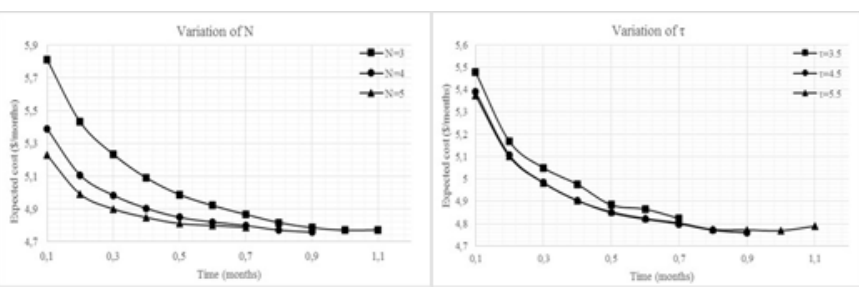

Fig. 6. Sensitive analysis of Scenario 1

As can be seen in Figure 7, the variation in Scenario 2 behaves differently than Scenario 1. By varying the value of $N$, the cost curves end up overlapping, with a very small variation in cost. When the value of $\tau$ is changed, a significant difference is observed when its value decreases, while when it increases, the expected value of the cost is very close to the optimum value. What we can observe is that despite the modifications, the lowest cost remains for the optimally presented value of $T, N$, and $\tau$.

Behavior similar to this is observed in Scenario 4 (Figure 9). When you change the value to $N$, there is an overlap of the expected cost curves. While the variation of $\tau$ gives an apparent difference in the curve, especially for a smaller value.

Figure 8 shows the variation for the expected cost curves for Scenario 3 , in which its behavior is similar to that presented in the Scenario 1 analysis. There is a distance between the curves for both the $N$ variation and the variation of $\tau$, but the latter when it is increased, is closer to the optimum curve.

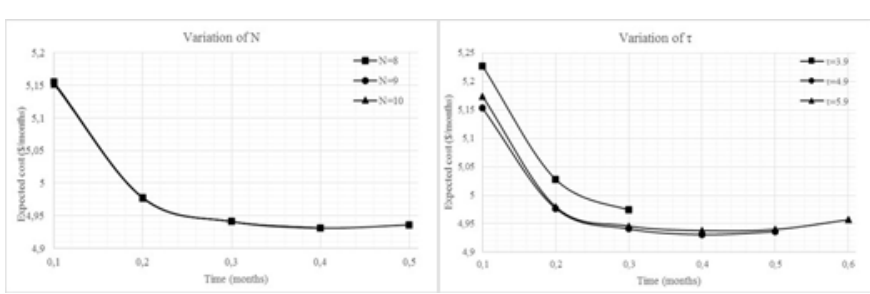

Fig. 7. Sensitivity Analysis of Scenario 2

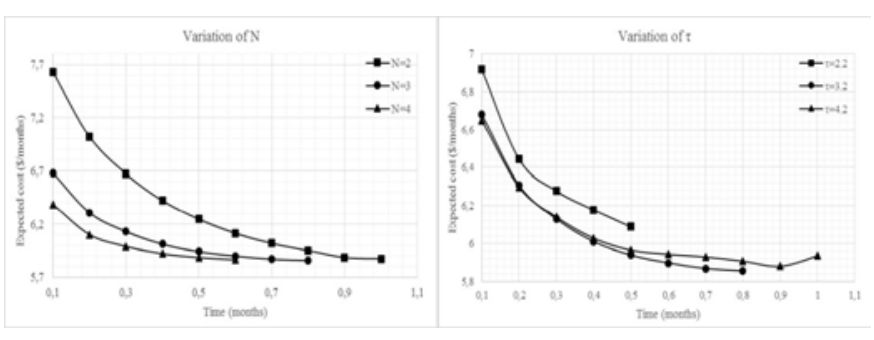

Fig. 8. Sensitivity analysis of Scenario 3

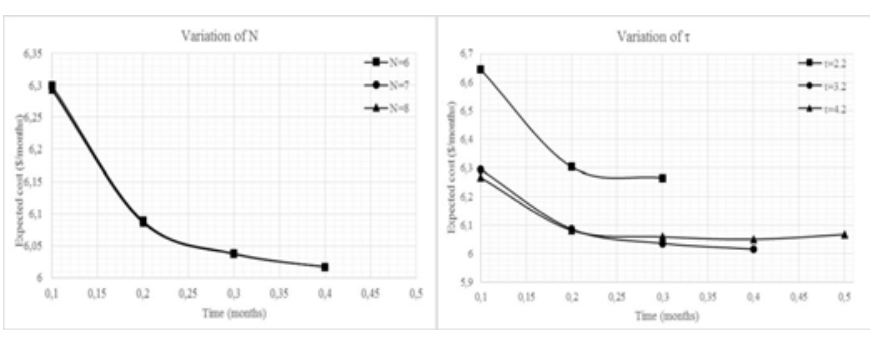

Fig. 9. Sensitivity analysis of Scenario 4

It should be emphasized that when there is a penalty cost, a greater variation in costs is obtained when the decision variables are modified. In addition, it should be noted that the curves have different sizes when related to $T$ values, since the decision variables are related to each other; increasing or decreasing one of them implies restricting values to the others.

Table 3 shows the behavior of the model according to variations in its input parameters.

It can be emphasized that, as expected, when changing cost values ( $c p, c B$, or $c d t$ ), only the maintenance cost value for the scenario in which this cost appears is modified. For example, by varying the value of the penalty cost of $B$, the behavior of the model remains the same for Scenarios 1 and 2, whereas for Scenario 3 when it is increased, a decrease in the time between inspections is observed as the limit $\tau$. While for Scenario 4, the time between inspections remains the same, but the limit $\tau$ and $N$ are decreased. A similar fact occurs in the variation for the cost penalty related to equipment $\mathrm{A}$.

Also worth mentioning is the behavior related to parameter $\lambda_{1}$ that represents the number of failures that occur per month. When this quantity was increased, that is, if there were more failures of A in one month, it was observed that the expected cost of maintenance and the time between inspections suffered decay. It is believed that this occurs because since A fails more, there is greater opportunity to perform inspections in $\mathrm{B}$, thus reducing the time it works in the defective state, in addition to preventing the occurrence of failure at the same time, which has a high cost impact for the model, whereas, the limit $\tau$ and $N$ increased.

In relation to the variations made in the parameters of $\mathrm{B}$, it can be verified that when $\beta$ is increased there is a tendency to decrease the intervals between inspections, concentrating the maintenance actions in a shorter lifetime. This is due to the characteristics of this parameter, in that when increasing its value, they are more concentrated on the origin in the time axis and more elongated in the axis of the values. In relation to the scale parameter of the Weibull distribution that 
Table 3. Behavior of model according variation of the parameters

\begin{tabular}{|c|c|c|c|c|c|c|c|c|c|c|c|c|c|c|c|c|c|c|c|c|c|c|c|c|c|c|}
\hline \multicolumn{11}{|c|}{ PARAMETERS } & \multicolumn{4}{|c|}{ SCENARIO 1} & \multicolumn{4}{|c|}{ SCENARIO 2} & \multicolumn{4}{|c|}{ SCENARIO 3} & \multicolumn{4}{|c|}{ SCENARIO 4} \\
\hline$\lambda_{1}$ & $\lambda_{2}$ & $\beta$ & $\eta$ & $c 1$ & c2 & cp & cr & $\mathbf{c F}$ & cB & cdt & $\mathrm{C}^{*}$ & $T$ & $\tau$ & $\mathbf{N}$ & $\mathrm{C}^{*}$ & $\mathbf{T}$ & $\tau$ & $\mathbf{N}$ & $\mathrm{C}^{*}$ & $\mathbf{T}$ & $\tau$ & $\mathbf{N}$ & $\mathrm{C}^{*}$ & $T$ & $\tau$ & $N$ \\
\hline \multirow[t]{3}{*}{1} & 0.66 & 2 & 5 & $0.1 C p$ & $0.5 \mathrm{Cp}$ & 1 & 10 & 25 & 10 & 1 & 4.759 & 0.9 & 4.5 & 4 & 4.931 & 0.4 & 4.9 & 9 & 5.856 & 0.8 & 3.2 & 3 & 6.017 & 0.4 & 3.2 & 7 \\
\hline & 0.5 & & & & & & & & & & 4.418 & 1.4 & 5.7 & 3 & 4.606 & 0.4 & 5.7 & 10 & 5.649 & 0.8 & 3.2 & 2 & 5.816 & 0.4 & 3.6 & 7 \\
\hline & 1 & & & & & & & & & & 5.267 & 0.9 & 3.6 & 3 & 5.427 & 0.4 & 4 & 7 & 6.172 & 0.7 & 2.8 & 3 & 6.334 & 0.4 & 3.2 & 6 \\
\hline 3 & & & & & & & & & & & 4.475 & 0.5 & 5.6 & 10 & 4.634 & 0.4 & 5.7 & 10 & 5.199 & 0.3 & 4.8 & 10 & 5.304 & 0.3 & 5.2 & 10 \\
\hline 2 & & & & & & & & & & & 4.562 & 0.5 & 5.6 & 10 & 4.685 & 0.3 & 5.8 & 10 & 5.413 & 0.5 & 4 & 7 & 5.513 & 0.2 & 4.5 & 10 \\
\hline 0.66 & & & & & & & & & & & 4.849 & 2.3 & 4.7 & 1 & 5.042 & 0.5 & 4 & 7 & 6.07 & 0.9 & 2.7 & 2 & 6.252 & 0.5 & 2.5 & 4 \\
\hline \multirow[t]{15}{*}{0.5} & & & & & & & & & & & 4.925 & 2.3 & 4.7 & 1 & 5.123 & 0.6 & 3.6 & 5 & 6.252 & 0.8 & 2.4 & 2 & 6.413 & 0.6 & 2.4 & 3 \\
\hline & & & 4 & & & & & & & & 5.62 & 2 & 4 & 1 & 5.888 & 0.5 & 4 & 7 & 6.999 & 0.8 & 2.4 & 2 & 7.18 & 0.5 & 2.5 & 4 \\
\hline & & & 4.5 & & & & & & & & 5.168 & 2.2 & 4.5 & 1 & 5.36 & 0.4 & 4.4 & 10 & 6.361 & 0.7 & 2.8 & 3 & 6.539 & 0.3 & 3 & 9 \\
\hline & & & 5.5 & & & & & & & & 4.417 & 1 & 5.1 & 4 & 4.568 & 0.5 & 5.6 & 10 & 5.428 & 0.6 & 3.6 & 5 & 5.571 & 0.4 & 3.6 & 6 \\
\hline & & & 6 & & & & & & & & 4.09 & 0.8 & 5.7 & 6 & 4.232 & 0.3 & 5.8 & 10 & 5.032 & 0.7 & 3.5 & 4 & 5.171 & 0.4 & 4 & 9 \\
\hline & & 1.5 & & & & & & & & & 5.574 & 1.3 & 5.3 & 3 & 6.926 & 0.7 & 5.7 & 7 & 8.342 & 1 & 4 & 3 & 8.553 & 0.5 & 4.5 & 8 \\
\hline & & 2.5 & & & & & & & & & 4.292 & 0.8 & 4 & 4 & 4.443 & 0.4 & 4.4 & 8 & 5.206 & 0.7 & 2.8 & 3 & 5.361 & 0.4 & 3.2 & 7 \\
\hline & & 3 & & & & & & & & & 4.024 & 0.8 & 4 & 4 & 4.159 & 0.3 & 4.2 & 10 & 4.817 & 0.6 & 3 & 4 & 4.96 & 0.5 & 3 & 5 \\
\hline & & & & & & 0.5 & & & & & 2.373 & 1.2 & 4.9 & 3 & 2.502 & 0.3 & 5.2 & 10 & 3.376 & 0.6 & 2.4 & 3 & 3.508 & 0.3 & 2.7 & 7 \\
\hline & & & & & & 2 & & & & & 9.493 & 0.9 & 4.5 & 4 & 9.706 & 0.6 & 4.9 & 7 & 10.644 & 0.9 & 3.6 & 3 & 10.854 & 0.6 & 3.6 & 5 \\
\hline & & & & & & 3 & & & & & 14.265 & 0.9 & 4.5 & 4 & 14.491 & 0.8 & 4.9 & 5 & 15.445 & 0.8 & 4 & 4 & 15.665 & 0.8 & 4 & 4 \\
\hline & & & & & & & & & 5 & & 4.755 & 0.9 & 4.5 & 4 & 4.922 & 0.4 & 4.9 & 9 & 5.322 & 0.9 & 3.6 & 3 & 5.496 & 0.4 & 4 & 9 \\
\hline & & & & & & & & & 15 & & 4.755 & 0.9 & 4.5 & 4 & 4.922 & 0.4 & 4.9 & 10 & 6.315 & 0.7 & 2.8 & 3 & 6.482 & 0.4 & 2.8 & 6 \\
\hline & & & & & & & & & & 0.5 & 4.755 & 0.9 & 4.5 & 4 & 4.853 & 0.5 & 5.1 & 9 & 5.84 & 0.8 & 3.2 & 3 & 5.943 & 0.3 & 3 & 5 \\
\hline & & & & & & & & & & 5 & 4.755 & 0.9 & 4.5 & 4 & 5.179 & 0.2 & 5.3 & 10 & 5.84 & 0.8 & 3.2 & 3 & 6.292 & 0.2 & 3.6 & 9 \\
\hline
\end{tabular}

represents the arrival of the defect for this equipment, a standard in the modification of the results regarding the decision variables is not observed. This can be a result of the randomness characteristic of the distribution, although decreasing the value of $\eta$ shows an increase in maintenance costs, since the arrival of the defect of B occurs before, and a decrease in that cost when this parameter is increased.

Still evaluating parameters related to equipment B we have $\lambda_{2}$, which represents the mean time between the arrival of the defect and the failure of this equipment through an exponential distribution. It can then be verified that as the arrival time of the fault increases, the maintenance cost decreases and, generally, the interval between inspections increases, as well as the limit $\tau$. In relation to $\mathrm{N}$, sometimes it holds and other times it decreases, because it is dependent on the values of the other decision variables as justified above.

\section{Conclusion}

The present paper showed maintenance based on random maintenance policy and simulation. It was possible verify that when a penalty cost is involved, the time required to perform a periodic inspection in the components is lowered, and consequently, the expected maintenance costs for the policy are higher. It was verified that the results obtained through a simulated procedure of parameters are satisfactory and occurs as expected, thus emphasizing the possibility of producing models for maintenance policies using simulated processes.

This was verified by applying the model in a real case, in which the behavior of this model was evaluated and tested. This real evaluation is important because it can be said that when the costs deal with large amounts of money, any savings realized could be a gain for the company, even gains that are not measurable such as consumer satisfaction through non-fulfillment of rework.

In the future, it is possible to suggest the aggregation of this model with other types of analysis, such as spare parts, besides considering imperfect maintenance through inspection failures.

\section{Acknowledgements}

The authors of the paper thank for CAPES - Coordenação de Aperfeiçoamento de Pessoal de Nivel Superior - for the financial support to the research, and FAPEMA - Fundação de Amparo à Pesquisa e ao Desenvolvimento Científico e Tecnológico do Maranhão.

\section{References}

1. Alaswad S, Xiang Y. A review on condition-based maintenance optimization models for stochastically deteriorating system. Reliability Engineering \& System Safety 2017; 157: 54-63, https://doi.org/10.1016/j.ress.2016.08.009.

2. Alrabghi A, Tiwari A. State of the art in simulation-based optimisation for maintenance systems. Computers \& Industrial Engineering 2015; 82: 167-182, https://doi.org/10.1016/j.cie.2014.12.022.

3. Alrabghi A, Tiwari A. A novel approach for modelling complex maintenance systems using discrete event simulation. Reliability Engineering \& System Safety 2016; 154: 160-170, https://doi.org/10.1016/j.ress.2016.06.003.

4. Babishin V, Taghipour S. Optimal maintenance policy for multicomponent systems with periodic and opportunistic inspections and preventive 
replacements. Applied Mathematical Modelling 2016; 40: 10480-10505, https://doi.org/10.1016/j.apm.2016.07.019.

5. Chen N, Ye Z-S, Xiang Y, Zhang L. Condition-based maintenance using the inverse Gaussian degradation model. European Journal of Operational Research 2015; 243:190-199, https://doi.org/10.1016/j.ejor.2014.11.029.

6. Chung C A. Simulation modelling handbook: a practical approach. United States of America: CRC Press LLC, 2004.

7. Dao C D, Zuo M. J. Selective maintenance of multi-state systems with structural dependence. Reliability Engineering \& System Safety 2017; 159: 184-195, https://doi.org/10.1016/j.ress.2016.11.013.

8. Darghouth M N, Chelbi C, Ait-kadi D. A profit assessment model for equipment inspection and replacement under renewing free replacement warranty policy. International Journal of Production Economics, 2012; 135: 899-906, https://doi.org/10.1016/j.ijpe.2011.10.029.

9. Dieulle L, Bérenguer C, Grall A, Roussignol M. Sequential condition-based maintenance scheduling for a deteriorating system. European Journal of Operational Research 2003: 150: 451-461, https://doi.org/10.1016/S0377-2217(02)00593-3.

10. Ding S-H, Kamaruddin S. Maintenance policy optimization-literature review and directions. International Journal of Advanced Manufacturing Technology 2015; 76:1743-1756, https://doi.org/10.1007/s00170-014-6341-2.

11. Duffua S O, Ben-Day M, Al-Sultan K S, Andijani A A. A generic conceptual simulation model for maintenance system. Journal of Quality in Maintenance Engineering 2001; 7: 207-219, https://doi.org/10.1108/13552510110404512.

12. Geng J, Azarian M, Pecht M. Opportunistic maintenance for multi-component systems considering structural dependence and economic dependence. Journal of Systems Engineering and Electronics 2015; 26: 493-501, https://doi.org/10.1109/JSEE.2015.00057.

13. Golmakani H R, Moakedi H, Optimal nonperiodic inspection scheme for a multicomponent repairable system with failure interaction using A* search algorithm. International Journal of Advanced Manufacturing Technology 2013; 67: 1325-1336, https://doi.org/10.1007/s00170012-4569-2.

14. Jardine A T J, Banjevic D. Optimizing condition-based maintenance decisions for equipment subject to vibration monitoring. Journal of Quality in Maintenance Engineering 1999; 5: 192-202, https://doi.org/10.1108/13552519910282647.

15. Laggoune R, Chateauneuf B, Aissania D. Opportunistic policy for optimal preventive maintenance of a multi-component system in continuous operating units. Computers \& Chemical Engineering 2009; 33: 1499-1510, https://doi.org/10.1016/j.compchemeng.2009.03.003.

16. Lam J Y J, Banjevic D. A myopic policy for optimal inspection scheduling for condition based maintenance. Reliability Engineering \& System Safety 2015; 144: 1-11, https://doi.org/10.1016/j.ress.2015.06.009.

17. Nourelfath M, Nahas M, Ben-Daya M. Integrated preventive maintenance and production decisions for imperfect processes. Reliability Engineering \& System Safety 2016; 148: 21-31, https://doi.org/10.1016/j.ress.2015.11.015.

18. Rezg N, Chelbi A, Xie X-L. Modelling and optimizing a joint buffer inventory and preventive maintenance strategy for a randomly failing production unit: analytical and simulation approaches. International Journal of Computer integrated Manufacturing 2005, 18: 225-235, https://doi.org/10.1080/0951192052000288152.

19. Sahraoui Y, Khelif R, Chateauneuf A. Maintenance planning under imperfect inspections of corroded pipelines. International Journal of Pressure Vessels and Piping 2013; 104: 76-82. https://doi.org/10.1016/j.ijpvp.2013.01.009

20. Scarf P A, Cavalcante C A V. Modelling quality in replacement and inspection maintenance. International Journal of Production Economics 2012; 135: 371-381, https://doi.org/10.1016/j.ijpe.2011.08.011.

21. Scarf P A, Cavalcante C A V, Dwight R A, Gordon P. An Age-Based Inspection and Replacement Policy for Heterogeneous Components. IEEE Transactions on reliability 2009; 58: 641-648, https://doi.org/10.1109/TR.2009.2026796.

22. Taghipour S, Banjevic D. Periodic Inspection Optimization Models for a Repairable System Subject to Hidden Failures. IEEE Transactions on Reliability 2011; 60: 275-285, https://doi.org/10.1109/TR.2010.2103596.

23. Thomas L C. A Survey of Maintenance and Replacement Models for Maintainability and Reliability of Multi-Item Systems. Reliability Engineering 1986; 16: 297-309, https://doi.org/10.1016/0143-8174(86)90099-5.

24. Yang L, Ma X, Zhai Q, Zhao Y. A delay time model for a mission-based system subject to periodic and random inspection and postponed replacement. Reliability Engineering \& System Safety 2016; 150: 96-104, https://doi.org/10.1016/j.ress.2016.01.016.

25. Yan H-C, Zhou J-H, Pang C K. Machinery Degradation Inspection and Maintenance Using a Cost-Optimal Non-Fixed Periodic Strategy. IEEE Transactions on Instrumentation and Measurement 2016; 65: 2067-2077, https://doi.org/10.1109/TIM.2016.2563998.

26. Zhang J, Huang X, Fang Y, Zhou J, Zhang H, Li J. Optimal inspection-based preventive maintenance policy for three-state mechanical components under competing failure modes. Reliability Engineering \& System Safety 2016; 152: 95-103, https://doi.org/10.1016/j. ress.2016.02.007.

27. Zhang X, Zeng J. A general modelling method for opportunistic maintenance modelling of multi-unit systems. Reliability Engineering \& System Safety 2015; 140: 176-190, https://doi.org/10.1016/j.ress.2015.03.030.

28. Zhao L, Chen M, Zhou D. General (N, T, $\tau$ ) Opportunistic Maintenance for Multicomponent Systems With Evident and Hidden Failures. IEEE Transactions on Reliability 2016; 65: 1298-1313, https://doi.org/10.1109/TR.2016.2570547.

29. Zhao X, Al-Khalifa K N, Nakagaw T. Approximate methods for optimal replacement, maintenance, and inspection policies. Reliability Engineering \& System Safety 2015; 144: 68-73, https://doi.org/10.1016/j.ress.2015.07.005.

30. Zhu W, Fouladirad M, Bérenguer C. Condition-based maintenance policies for a combined wear and shock deterioration model with covariates. Computers \& Industrial Engineering 2015; 85:268-283, https://doi.org/10.1016/j.cie.2015.04.005.

\section{Mônica Frank MARSARO}

Department of Mechanical and Production Engineering

State University of Maranhão - UEMA

University City Paulo VI - post office box 09, São Luís - MA

- Brazil - Zip Code: 65055-970

\section{Cristiano Alexandre Virgínio CAVALCANTE}

Department of Production Engineering

Federal University of Pernambuco - UFPE

Professor Moraes Rego Avenue, 1235 - University

City, Recife - PE - Brazil - Zip Code: 50670-901

E-mails:mmarsaro@gmail.com, cristianogesm@gmail.com 